\title{
The Meaning of Monument in the Life of Toba Batak Tribe in Palipi Subdistrict, Samosir Regency, Indonesia
}

\author{
Ulung Napitu ${ }^{1}$, Corry $^{1}$, Resna Napitu ${ }^{2}$, Supsiloani $^{3}$ \\ ${ }^{1}$ Faculty of Teacher Training and Education, Universitas Simalungun, Indonesia \\ ${ }^{2}$ Faculty of Economic, Universitas Simalungun, Indonesia \\ ${ }^{3}$ Anthropology Study Program, Universitas Negeri Medan, Indonesia \\ ulungnapitu2018@gmail.com
}

\begin{abstract}
This study aims to analyze the meaning of monument in the life of Toba Batak tribe in Palipi Subdistrict, Samosir Regency. This research uses descriptive analytic method with phenomenology approach. Researchers in the phenomenological view try to understand the meaning of events and their relation to ordinary people in certain situations. The results of this study indicate that the monument is one place that will unite a clan and clan groups. The monument in Toba Batak community in Samosir is called the Procurement Monument where with the monument, a clan group will more often make offerings to its ancestors. In addition, with the existence of the monument, it is expected that fellow clans will meet and silaturrahmi relations will be maintained between clan relatives. In this study there were six monuments discussed as samples, namely Sitohang clan, Sinaga clan, Situmorang clan, Toga Pandiangan Tugu clan which was found in Palipi Subdistrict.
\end{abstract}

Keywords meaning monument; Batak tribe; Indonesia

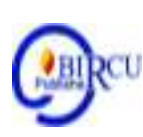

\section{Introduction}

Toba Batak tribe from ancient times until today still retains the traditional values inherited from their ancestors, although sometimes they are contrary to religious teachings but are still maintained. Therefore it is important that there is a process of adaptation, acculturation of socio-cultural values with religion that is adapted to today's life.

The tradition of the construction of the mangongkal holi monument and the strained panangkok saring-saring is one of Batak Toba traditions with the aim of honoring the ancestors and spirits of parents. Through this series of events it is believed that hasangapon, hagabean and hamoraon will be obtained for each clan, clan group or hereditary group. The monument that was ready to be built (tambak na timbo and batu napir) in it was provided where the ancestral bones were placed first, while the youngest were the lowest placed in pairs (husband and wife) (Situngkir, 2011: 3).

The factors underlying the construction of the monument (tambak na timbo) among Toba Batak tribe are: The factors underlying the construction of the monument (tambak na timbo) among Toba Batak tribe, namely:

1. There is a desire to elevate the social, personal and family status of the clan in the yard which reflects that their offspring are rich, successful and the belief that success is inseparable from the blessing (blessing) of the spirits of the ancestors (sumangot).

2. Identity of the clan unifier / and descendants of one ancestor called sa'ompu.

3. Toba Batak Belief that humans consist of flesh (body), breath (hosa), and spirit (tondi). If a human dies his body returns to the ground, the breath (hosa) returns to the wind 
Konfrontasi Journal: Culture, Economy and Social Changes, 7 (2) June 2020, 124-136

ISSN: 1410-881X (Print), 2716-2095 (Online)

Ulung Napitu, Corry, Resna Napitu, Supsiloani: The Meaning of Monument in the Life of Toba Batak Tribe in Palipi Subdistrict, Samosir Regency, Indonesia

DOI: https://doi.org/10.33258/konfrontasi2.v7i2.106

http://www.konfrontasi.net/index.php/konfrontasi2

(alogo), and the spirit (tondi) becomes delicate (spirit). Begu, sumagot and sombaon will

give blessings to their offspring who are still alive (Pasaribu, 2011: 15).

Based on the description above, the purpose of the study is the meaning of monument in the life of Toba Batak tribe in Palipi Subdistrict.

\section{Review of Literatures}

Nowadays phenomenology is known as a philosophical school as well as a method of thinking that studies human phenomena without questioning the causes of these phenomena, the reality of their objects and their appearance, Munir in Napitu, (2020). Phenomenology does not depart from the truth of phenomena as they appear as they are, but strongly believes that the phenomena that appear are objects that are full of transcendental meanings, Kuswarno in Napitu, (2020). Therefore, to obtain the essence of truth, it must break through and surpass visible or visible phenomena, Basrowi in Napitu, (2020). The main purpose of phenomenology is to study how phenomena are experienced in mind consciousness, and in action, such as how these phenomena are valued or accepted aesthetically, Kuswarno in Napitu, (2020).

Phenomenology seeks to understand how humans construct meaning and conceptual concepts in terms of intersubjectivity, because our understanding of the world is shaped by our relationships with others. Meaning is an important element in human life. Regarding feelings about what is wanted or not wanted, about what may and may not be done and about what is valuable and what is not valuable (P. Murroisa in napitu, 2020). Although the meaning that we create can be traced in the actions, works and activities that we do, there are still other people's roles in it

The term phenomenology is used in the main sense, that is, between theory and methodology. In the philosophy of science, the term phenomenology is not used in the main sense only once. This is what made it unknown until near the 20th century (Schutz, 1972: xxxxi). Husserl's main ideas about phenomenology:

1. Phenomena are their own realities (reality in se) that appear.

2. There is no boundary between subject and reality.

3. Awareness is intentional

4. There is an interaction between the act of consciousness (noesis) with the object being realized (noema) (Kuswarno, 2009: 34)

Referring to the view of Immanuel Kant (1724-1804), which states that, everything consists of numerology (ideas, concepts or thoughts) and phenomenology (congress objects, material that can be touched). Both of these are also found in the teachings of Christianity, religious teachings other and other beliefs. In culture universally the two things above (nemonology and phenomenology) are also found in Toba Batak culture.

When the religious life that exists in the Batak land brought by evangelists from Europe brought a flow of Fietism, which is to teach the Batak tribe to live holy and holy spiritually and try to separate themselves from their daily lives. This doctrine of dietism eliminates its culture and uses European culture to fill its daily life. This gave rise to a reaction or resistance to cultural nationalism, namely that the church wanted to eradicate Toba Batak culture and display western culture in their daily lives. At that time Toba Batak tribe sought to understand Christianity and Batak Toba culture together. It was at this time that Toba Batak culture emerged to build a monument (tambak na timbo). Therefore the construction of the monument is a phenomenology and has a phenomenology. 
To study the phenomenon and meaning of development, the study uses a phenomenological approach with a qualitative research model, because what is intended to be understood is not only the factors causing the development of the monument which are associated with various cultural, ethnic and psychiatric aspects but also the background of the phenomenon to be able to express the meaning of subjective actions from Toba Batak tribe.

The assumption underlying this study is that the meaning of the construction of the monument can be found subjectively, if this action is examined in depth, breaking through everything that is behind the visible phenomenon, in accordance with the experience of the clans that have carried out the construction of the monument. The phenomenology put forward by Schurtz teaches that each individual is present in the stream of consciousness that is obtained from the process of reflection on everyday experiences. Assuming the reality of other people who are mediated by ways of thinking and feeling, reflecting the past is passed on to others through social relations (Campbell, 1994: 235). That the social world is an intersubjective and meaningful experience. Phenomenology emphasizes the meaning of action, identical with the motives that drive one's actions (older-to motive). Thus to understand individual human actions must be seen from the motives that underlie these actions. Furthermore Schutz added that with the motives underlying the actions or because of motives we can see the meaning of actions in accordance with the original motives that are true underlying the actions carried out individually (Water, 1994: 33).

\subsection{Semiotic Theory: Symbols, Signs, and Construction of Meanings}

The term semiotic comes from the Greek word, semeion which means sign theory. Another opinion put forward by Hartoto (1984: 42) which states that semiotics is the way the work is interpreted by observers and the community through signs and symbols. Based on this, that semiotics as a science is studying the life of signs in a broad sense in society both straightforward and classy using language and non-language (Rusmana, 2014: 23). Semiotics is divided into nine types, namely:

a. Analytical semiotic is a semiotic that produces a sign system

b. Descriptive semiotics are semiotics that pay attention to the sign system that can be experienced by everyone, even though there is a sign since the past it remains as witnessed today.

c. Faunal semiotics are semiotics which have signs from animals when communicating between them by using certain signs that some of them can understand by some humans.

d. Cultural semiotics, namely semiotics specifically examines the sign system that applies in a particular society's culture.

e. Narrative semiotics are semiotics that examine the sign system in the narrative in the form of myths and oral stories.

f. Natural semiotics namely semiotics specifically examine the sign system produced by nature.

g. Semitic normative is semiotic which specifically examines the sign system created by humans and manifests the norms.

h. Social Semiotics is a semiotic that specifically examines the sign system produced by humans in the form of symbols and sentences.

i. Structural semiotics, namely semiotics that specifically examine the sign system that is manifested through the structure of language (Pateda, 2001: 29).

The things that need to be discussed in semiotics are as follows:

a. Signs are a reflection of symptoms that have a number of criteria such as name, role, function, purpose and meaning. 
b. Symbols or symbols are things or conditions that guide the subject's understanding of the object.

c. Icons are the relationship between signs and references in the form of similarity.

d. Index is interpreted by the relationship between signs and references that arise because of the closeness of existence.

e. Sign is a matter and condition given by subject to object through non-verbal language or non-verbal language (Rusmana, 2014: 39-45).

Semiotics is a form of development that underlies the formation of an understanding that refers to the formation of a meaning that can never be separated from the meaning, perception, or understanding of whatever we see. Scientific studies that examine symbols or signs and the construction of meaning contained in these signs are called Semiotics. Semiotic tradition consists of a set of theories about how signs represent objects, ideas, circumstances, situations, feelings and conditions outside the signs themselves (Littlejohn, 2009: 53).

Semiotic aims to find out the meanings contained in a sign or interpret meaning so that it is known how the community constructs the meanings contained in a symbol or symbol. This concept of meaning cannot be separated from certain ideological perspectives or values as well as cultural concepts which are the realm of the thinking of the people where the symbols were created. Cultural code which is one of the factors in the construction of meaning in a symbol becomes an important aspect to determine the message construction in the sign.

It is this construction of meaning that forms the basis of the formation of ideology in a sign. As one of the studies of thought in cultural studies, semiotics certainly sees how culture is the rationale for the formation of meaning in a sign. Semiotics study systems, rules, conventions that allow these signs to have meaning (Kriyantono, 2007: 261).

The figures in semiotic studies are Roland Barthes. Barthes is a figure that is so identical to semiotic studies. Barthes's semiotic thinking can be said to be the most widely used in research. As the successor of Saussure's thought, Roland Barthes emphasizes the interaction between the text with the personal and cultural experiences of its users, the interaction between conventions in the text and conventions experienced and expected by its users (Kriyantono, 2007: 268). Barthes's operational concept of thought is known as the Order of Signification. Put simply, Barthes's semiotic study can be described as follows:

1. Denotation is a real meaning, or a phenomenon that appears with the five senses, or can also be called a basic description.

2. Connotation is a cultural meaning that appear or can also be called meanings that arise because of cultural construction so that there is a shift, but still attached to the symbol or sign.

Two aspects of the study from Barthes above are the main studies in researching about semiotics. Then Barthes also includes aspects of myth, which is where when the connotation aspect becomes popular thought in the community, and then myths have been formed on these signs. Barthes thought is considered the most operational so often used in research.

According to Charles Sanders Pierce: Semiotic analysis consists of three important aspects so it is often called a triangle of meaning (Littlejohn, 1998). The three aspects are:

1. Signs, in semiotic studies, signs are the main concept used as material for analysis in which signs contain meaning as a form of interpretation of the intended message. Put simply, signs tend to be visual or physical in nature that are captured by humans.

2. Reference to a sign or object, an object is a social context in which its implementation is used as an aspect of meaning or as referenced by the sign. 
3. Sign users (interpretant), the concept of thought of people who use the sign and reduce it to a certain meaning or meaning that is in someone's mind about the object to which a sign is referred (Kriyantono, 2007: 263).

\section{Research Methods}

This research uses descriptive analytic method with phenomenology approach. Researchers in the phenomenological view try to understand the meaning of events and their relation to ordinary people in certain situations. Phenomenological sociology is basically strongly influenced by the views of Edmund Husserl and Alfred Schultz. Another influence comes from Weber who put pressure on versteheen, namely interpretive understanding of human understanding. Phenomenology does not assume that researchers know the meaning of something to the people being studied.

The location of this research is in Palipi Sub-district, Samosir Regency. In this study the research informants were divided into two groups, namely the main informant and the base informant. The criteria used as a reference for selecting informants in accordance with phenomenological research are:

a. The informant must experience firsthand the situation or incident related to the research topic,

b. The informant is able to re-describe the phenomena he has experienced, especially in their nature and meaning,

c. Willing to be involved in research activities for a long time,

d. Willing to be interviewed and recorded its activities during the interview or research in progress.

e. Give consent to publish the results of research (Kuswarno, 2009: 61).

Data collection techniques through in-depth interviews and participatory observation carried out to obtain the primary data or principal needed by researchers. All data collected was analyzed qualitatively. In general, the presentation of collected data is directed to explain the implementation of the construction of the monument (tambak na timbo) and other rituals performed by Toba Batak community. Triangulation by utilizing sources by comparing and checking back the degree of trust in information obtained through different time and tools, namely (1) comparing observational data with interview data; (2) comparing one's circumstances and perspectives with various opinions of people such as ordinary people, middle or high educated people, wealthy people, government people; (3) comparing the results of the interview with the contents of a related document.

\section{Discussion}

\subsection{The Meaning of Sihotang Clan Monument}

Sitohang is one of the clans of Batak (Toba) in Samosir Regency. Sitohang clan originates from the village of Urat in Palipi Sub-district, Samosir Regency, North Sumatra Province. Sitohang clan belongs to Lontung class. From Urat Samosir, the ancestors of the Sitohang clan migrated to various regions and opened a new village (lumban). Among the several destinations for the ancestors of Sitohang clan are in Dairi and Baringin Parbuluan in Humbang Hasundutan. From there the descendants of Sitohang clan scattered throughout the world. In Dairi land, the descendants of Sitohang clan even succeeded in becoming the Regent, namely Jonathan (Ompu Tording) Sitohang and KRA Johnny Sitohang Adinagoro. 


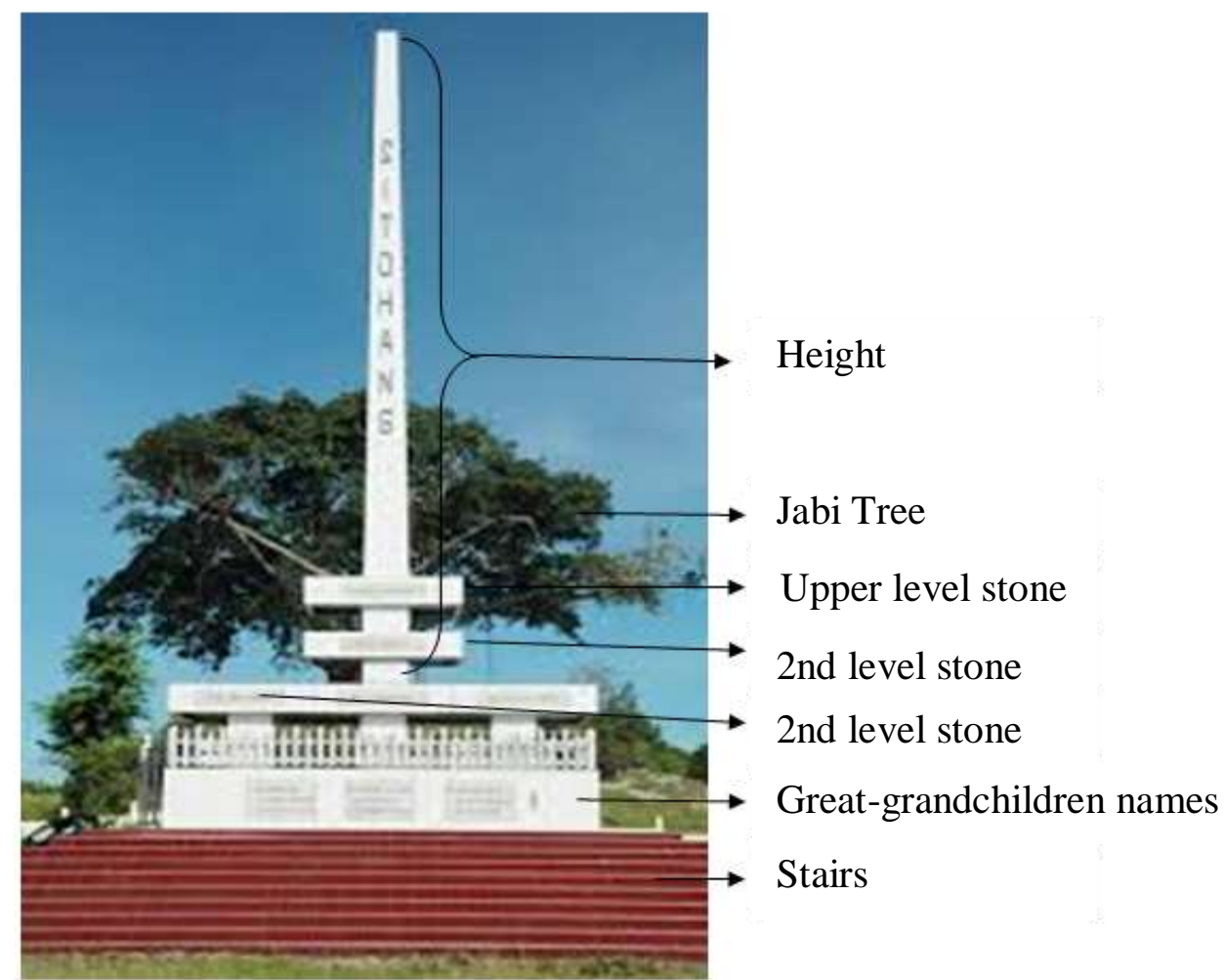

Figure 1. Sihotang Clan Monument

The meanings attached to Sitohang Toga Monument are based on the results of interviews with Oktavia Sitohang, Joko Sitohang, Muhammad Maji Sitohang and amani Pasti Simbolon explained as follows:

\section{a. Height Monument}

The height of the existing pillar in Toga Sitohang monument is "17 meters", this symbolizes the 17th generation of Sitohang clan", meaning that the number of generations of Sitohang clan at the time the determination of Toga Sitohang monument development plan in 1966 was already 17 th generation.

\section{b. Jabi Tree}

Jabi-jabi tree serves to mark the boundaries of the region. Every burial place has always been planted with hard trees that can live for thousands of years. At first the first burial (primary burial) was carried out by burial of the body in the ground. As a sign that the grave does not disappear, on top of the grave planted hard types of hariara, jabi-jabi, baringin, bintatar. This type of grave functions as a permanent grave, where the bones are not dug out anymore because it is integrated with a tree that has grown large. The remains of this type of grave are still commonly found in the field.

\section{c. Upper Level Stone}

The upper level stone symbolizes Ompu Tuan Situmorang, who is the first descendant of Situmorang clan. This is one of the first ancestors of Situmorang clan. So the top-level stone signifies Ompu Tuan Situmorang who is Ompu from Sitohang Clan.

\section{d. $2^{\text {nd }}$ Level Stone}

The second level above symbolizes that Ompu Tuan Situmorang has two sons, Panopa 
Raja Situmorang and Ompu Pangaribuan. This is what symbolizes the second lineage of the Sitohang clan.

\section{e. $3^{\text {rd }}$ Level Stone}

In the Third Level from the Top is a stone that symbolizes that Ompu Tuan Situmorang has grandchildren of his two children as many as three people, namely from Panopa Raja Situmorang, having two children named Ompu Ambolas Situmorang and Ompu Parhujobung Situmorang. While from Ompu Pangaribuan Situmorang, he has one son, namely Raja Babiat Situmorang.

\section{f. Cicit Names}

On the bottom wall, carvings of the great-grandchildren of Ompu Tuan Situmorang who are children of Ompu Ambolas Situmorang, namely Raja Pande Situmorang and Lumban Nahor Situmorang. Furthermore, the son of Ompu Parhujobung Situmorang who has a child named Suhut Ni Huta Situmorang and Mr. Siringo-Ringo Situmorang. While the son of Raja Babiat Situmorang has three children named From Mangabat Situmorang (Sitohang Uruk), Raja Itubugna (Sitohang Tonga-Tonga) and Ompu Bona Ni Onan (Sitohang Toruan).

\section{g. Stairs}

The stairs symbolize the symbolic symbol that grandchildren from Sitohang have seven children. The 7 steps in this illustrate that Mr. Sitohang has seven great-grandchildren. As for his great-grandchildren, namely (1) Raja Pande Situmorang, (2) Lumban Nahor Situmorang, (3) Suhut Ni Huta Situmorang (4) Mr. Siringo-Ringo Situmorang (5) From Mangabat Situmorang (Sitohang Uruk), (6) Raja Itubugna (Sitohang Tonga-Tonga) and (7) Ompu Bona Ni Onan (Sitohang Toruan).

\subsection{Toga Sinaga Clan Monument}

In 1964 at the initiative of several people from this pomparan who live in Medan, they tried to develop PPTSB activities by contacting Toga Sinaga figures in Medan. This activity received good reception and support from all walks of life. The existence of Major Police Drs. M. H. Sinaga who was moved from Jakarta to Medan as Assistant II of KAPOLDASU welcomed the increase in PPTSB activities, who were willing to be active as members of the management.

To realize the ideas of the PPTSB activities, meeting meetings were held from Pomparan Toga Sinaga in Medan. Based on the results of meetings held several times, as the initiator of the erection of this monument, Ama Roma Sinaga (Ompu Koko) gave an explanation of the agreement that had been obtained from the meeting, namely:

"Toga Sinaga Monument is very important to be erected because it has a very big goal, namely as a unifying tool for all of Toga Sinaga Pomparan that is developing on this earth. It is time for us Sinaga clan to prove itself remains one in the outside world, where we continue to use the designation of Sinaga clan and not Marsiolian (blood marriage). The unity in the designation of Sinaga must be maintained and preserved by establishing Toga Sinaga Monument in our Bonapasogit ". 


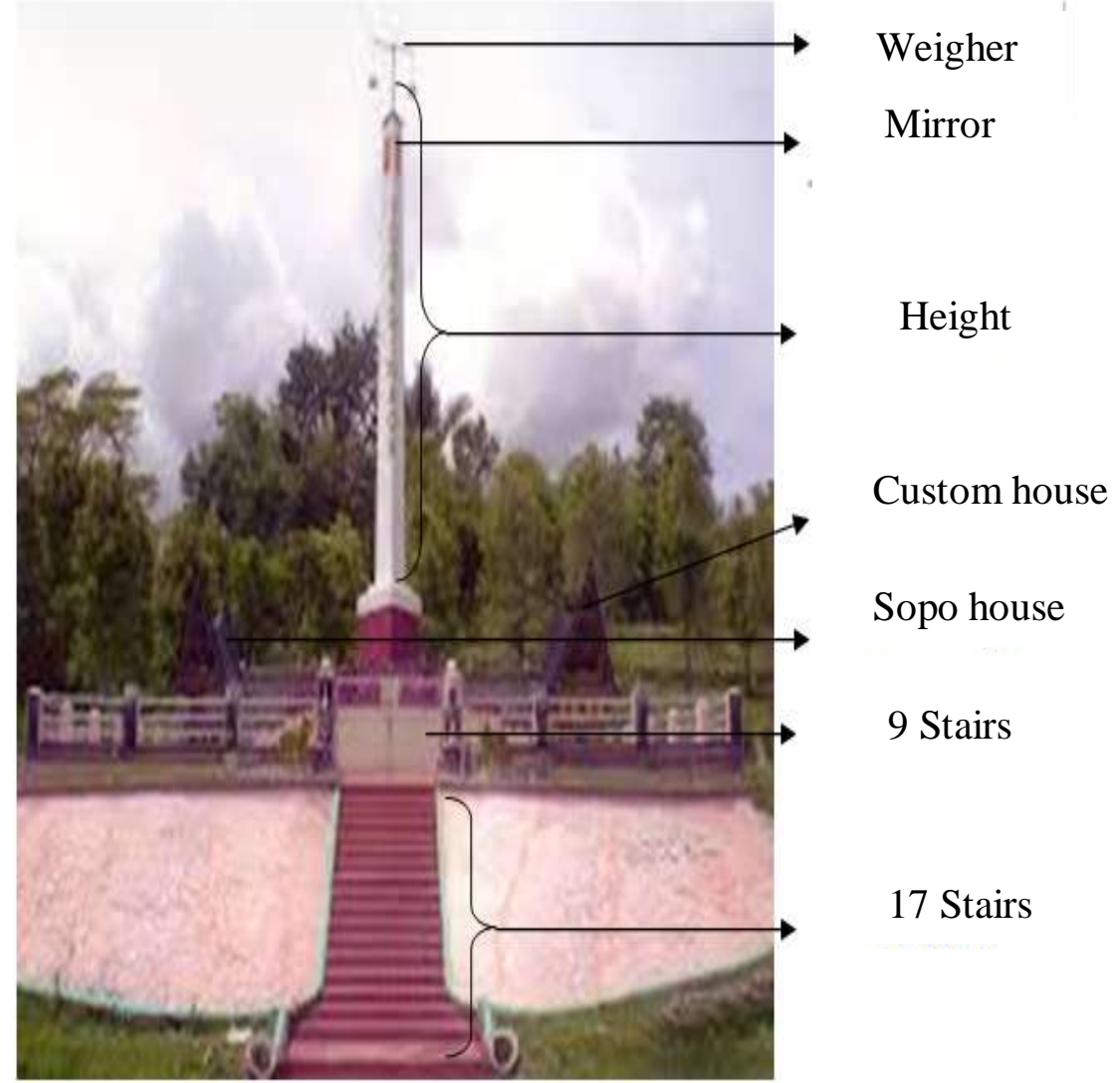

Figure 2. Toga Sinaga Clan Monument

The meaning of the form and completeness of the Symbols in Sinaga monument based on the results of interviews with Risma Naibaho, Mardin Sinaga, Rusdi Sinaga, Muhhamad Taufik Sinaga and Tarmaisi Sinaga are as follows:

\section{a. Tugu Height}

The height of Toga Sinaga Monument is "17 meters", which symbolizes the "17th Generation of Sinaga", which means that the number of generations (of Sundanese) of the Marga Sinaga at the time of the plan to establish the construction of Tugu Sinaga Monument in 1966 was 17 th generation.

\section{b. Batang Tugu}

The monument is shaped "Isosceles Triangle", which symbolizes "Toga Sinaga Si Tolu Ompu", namely:

- Sinaga Bonar.

- Sinaga Ratus.

- Sinaga Uruk (Sagi Raja).

\section{c. Number of Steps}

The number of steps in the monument is as much as "9 (nine) steps", which symbolizes "toga sinaga si sia ama," or there are nine grandchildren of Sinaga, namely:

- Sinaga Bonar Pande.

- Sinaga Bonar Pole Ditonga. 
- Sinaga Bonar Suhut ni Huta.

- Sinaga Ratus Nagodang.

- Sinaga Ratus Sitinggi.

- Sinaga Ratus Siongko.

- Sinaga Uruk Hatahutan.

- Sinaga Uruk Barita Raja.

- Sinaga Uruk Datu Hurung.

\section{d. Miniature Traditional Houses besides the Monument}

The miniature traditional house building located on the right-hand court of the monument symbolizes Jabu Parsantian (heritage house). The traditional house is a carved Batak traditional house.

\section{d. Miniature House of Sopo}

The miniature building of the Sopo House, which is located on the left side of Toga Sinagugu Monument, symbolizes the house or storage area for rice and heirlooms.

\section{e. Miniature Fig Tree (Maranak Jabi)}

Miniature Fig Tree (Maranak Jabi) made of iron which symbolizes "Fertility or Growth" of the descendants of Toga Sinaga (hagabeon).

\section{f. Mirror glass under the tip of the monument}

The mirror that is located at the end of the monument on three sides, symbolizes "Self Introspection", namely that Sinaga clan in every thought, talk, act and plan everything must be "full of accuracy" so that there are no mistakes.

\section{g. Miniature Death (Scales)}

Miniature Hatian (scales) which is located at the very top end of the monument, symbolizes the nature of "Justice" which is a reflection of the nature inherent in the 12th Ompu Palti Raja Sinaga who during his life always behaved and acted fairly, honestly and sincerely, so the 12th Ompu Palti Raja Sinaga was given the nickname, as follows:

- Ompu Palti Raja

- Ompu Palti Pandapotan

- Par Ninggala Sibola Tali (Reflecting Honesty)

- Par Hatian na Sora Monggal (Describing Justice)

- Par Parik Sinomba ni Gajah, naso tarangkat manuk sabungan (Reflects strong and tough spirit).

Hatian (the scales) and the five nicknames of the 12th Ompu Palti Raja Sinaga, illustrate the appeal to all descendants of Toga Sinaga so that in their lives always behave and act fairly, honestly and sincerely with a strong and tough spirit in social life.

\subsection{Situmorang Clan Monument}

The Situmorang clan is a Sipitu Ama monument on earth that cannot be denied anymore. Even the descendants of Ompu, Mr. Situmorang Sipitu Ama, are everywhere in the world (portibion). To perpetuate the name of Ompu Tuan Situmorang and his descendants, on 5-7 July 1990, the Ompu Tuan Situmorang monument was built and inaugurated. Tugu Ompu Tuan Situmorang, ancestor of the descendants of Situmorang Sipitu Ama, is located in Urat Village, Palipi sub-district. 


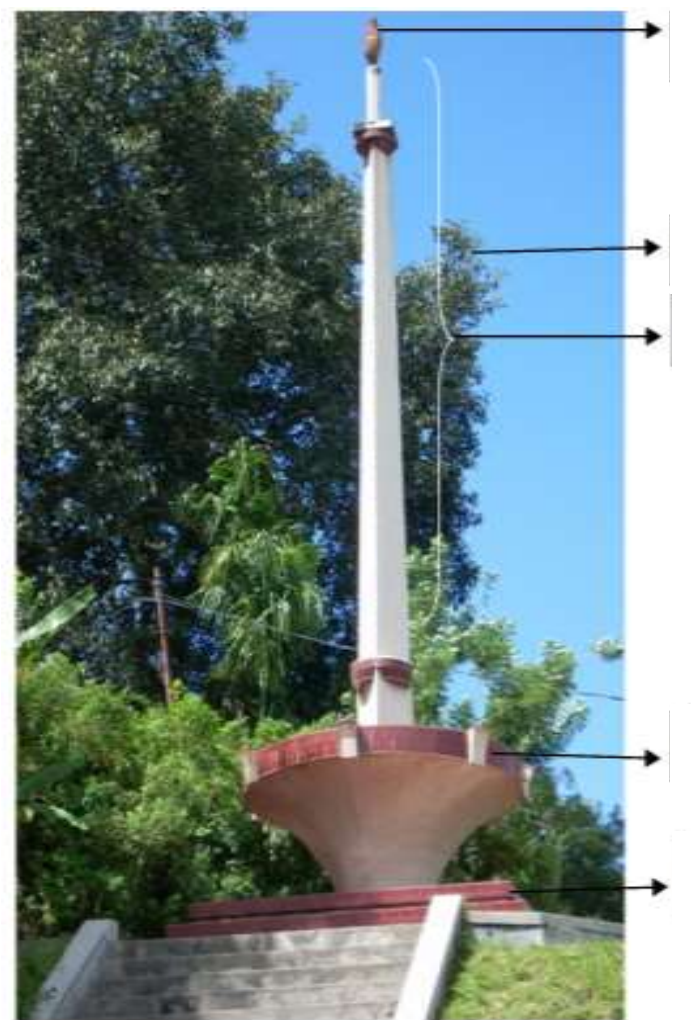

Figure 3. Situmorang Clan

\section{Candle}

Jabi-jabi tree

The height of the pillar is $17 \mathrm{M}$

Betel Place

Stair 3

The meanings contained in the symbols in Situmorang Monument are based on interviews with Risma Naibaho, Batu Alfonso, Nelson Situmorang, Mudin Sihaloho and Muhhamad Majid Sitohang as follows:

\section{a. Candles}

The candle above the golden yellow pillar symbolizes the lighting. With this, the ancestors wanted the next generation to be able to become lights and all would become successful people like lights in the dark that always illuminate the people around them. As explained by Nelson Situmorang (Ompu Situmorang) as follows:

"The candle on the pillar means that the successors of the Simatondang clan will always be the lights and continue to be successful people in daily life or in society. So it is a form of dreams or hopes from the ancestors who are always the Situmorang clan, always shining.

\section{b. Jabi-jabi tree}

Jabi tree in the burial area was intentionally planted as evidence that Jabi tree is a tree that can last for thousands of years. In addition, Jabi-jabi tree is a tree that has become a hallmark of Batak culture, which was descended from several early generations, precisely when the area around Lake Toba had not been entered by religious teachings. To be a role model for life, most Batak people believe in the existence of this tree as a determinant of life and decision making. Jabi Tree was used by several traditional elders in one village to make decisions when building a settlement.

Jabi tree is believed by the community to protect a village from all distress. Even today Jabi tree is also still used by some Batak people as a place to carry out an agreement or as a symbol of the clan. In Batak Culture information note, this tree is called Jabi which has meaning as a prosperous life. This is interpreted from some of the cultural philosophies of 
Batak people in the section contained in Jabi-jabi tree.

As in the leaf which has the meaning of protection from all distress, the stem which has the meaning of a bearer of fortune and blessing, and then the root part which has the meaning of unity between humans and humans and harmony with nature around it. So the philosophy contained in this tree is now be an advice for Batak people to be able to live like a Jabi-jabi tree that can be useful for others.

\section{c. Tugu Height}

The height of Situmorang Toga Monument is "17 meters", which symbolizes the height and symbolizes the "17th Situmorang Generation", which means that the number of generations of Sinaga Clan at the time of the determination of Toga Sinaga monument development plan has reached the generation the 17 th.

\section{d. Stair 3}

The number of stairs to Toga Ompu Tuan Situmorang staircase is 3 (nine) stairs, this symbolizes the notolo meaning that the stove is three of the social structures of Toba Batak community which consists of (a) Dongan Tubu (One Marga), (b) Hula-hula (family giving wife) and (c) Boru (Daughter of a certain clan).

\subsection{Pandiangan Clan Monument}

Toga Pandiangan is the third child of Raja Lottung, Toga Pandiangan monument is located in Urat, Palipi Sub-district, Samosir Regency, North Sumatra. From the list and sequence of tarombo above it can be seen that Samosir Pakpahan, Gultom, Harianja, Sitinjak are part of Pandiangan clan. And they should have used Pandiangan clan as their identity (Pandiangan Samosir, Pandiangan Gultom, etc.), but some of them did not include Pandiangan in front of their clan.

Tandi Pandiangan Monument is one form of unity and unity of the descendants of the Pandiangan toga clan. Pandiangan Toga has two children namely Toga Batu (Batuara, Parhusip) and Toga Sihombar (Rumahombar, Pinaungan, Lumban Siantar, Hutabalian) Lumbantungkup, Lumbanraja. And in 2005 Pandiangan toga monument was restored for the second time in seven davs and seven nights.

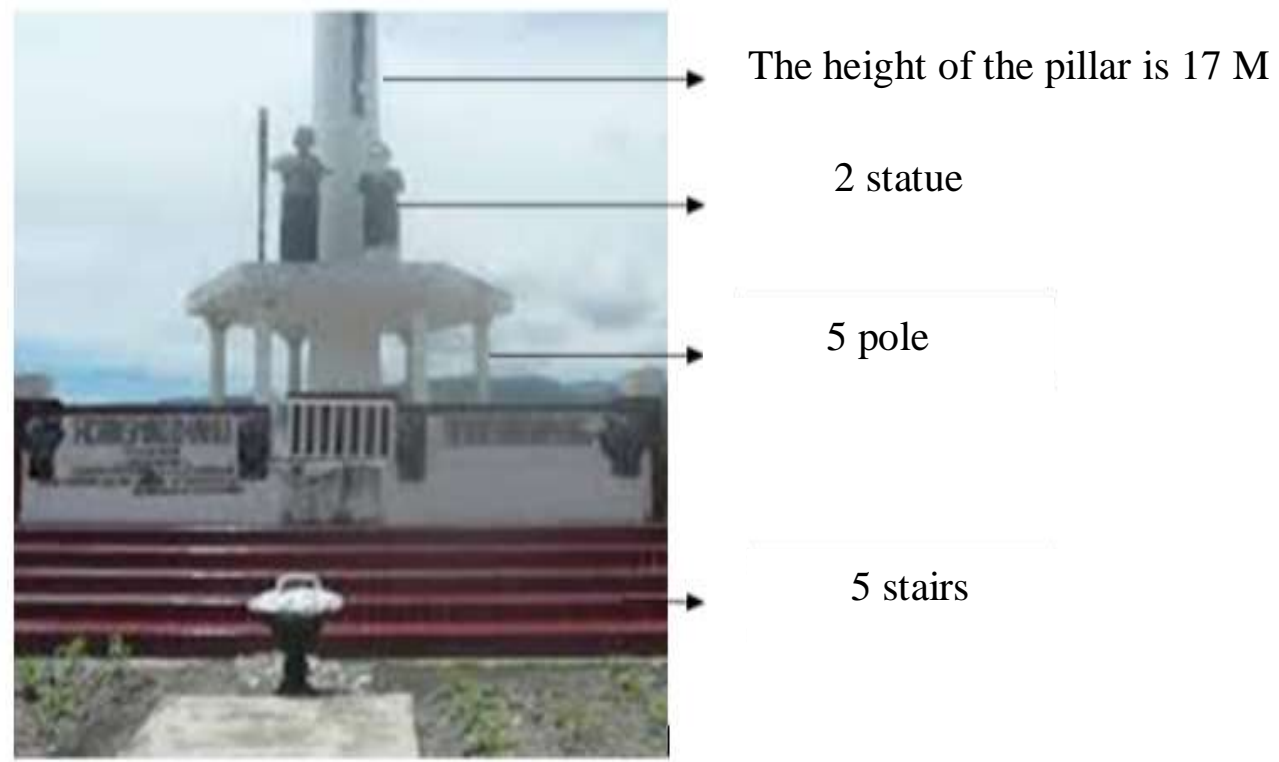

Figure 4. Pandiangan Monument 
The meaning of the symbols and symbols of Pandiangan monument based on the results of interviews with Ramot Sirait, Halomoan Sidabutar Nermika Pandiangan Joko Sitohang and Timbang Simbolon are as follows:

1. The height of the monument $17 \mathrm{M}$

Waiting height for Pandiangan Toga is as high as 17 meters, which symbolizes that the number of generations with the surname Pandiangan at the time of the determination of the Tugu Toga Sinaga development plan in 1988 was the 17th generation.

2. Sculpture

The statue in the middle of the monument symbolizes Ompu Toga Pandiangan and his wife surnamed Boru Sagala.

3. 5 Mast

Five poles symbolize the descendants of Pandiangan from King Humirtop Pandiangan and Raja Sonang Pandiangan, the son of Pandiangan humirtop named Mr. Raja Pande Pandiangan and Mr. Suhut Pandiangan. While from King Sonang Pandiangan named Gultom Pandiangan, Samosir Pandiangan, Pakpahan Pandiangan and Sitinjak Pandiangan.

4. 5 Steps

Five steps symbolize the great-grandchildren of Ompu Toga Pandiangan named: (a) Raja Humirtop Pandiangan, (b) Raja Sonang Pandiangan, (c) Boru Saroding Pandiangan, (d) Boru Menag Enak Pandiangan and (e) Boru Nahumot Pandiangan.

\section{Conclusion}

The monument is one place that will unite a clan and clan groups. The monument in Toba Batak community in Samosir is called the Procurement Monument where with the monument, a clan group will more often make offerings to its ancestors. In addition, with the existence of the monument, it is expected that fellow clans will meet and silaturrahmi relations will be maintained between clan relatives. In this study there were six monuments discussed as samples, namely Sitohang clan, Sinaga clan, Situmorang clan, and Toga Pandiangan clan monument which was found in Palipi Sub-district.

\section{References}

Agustian, Murniati. 2015. Multicultural Approach. Jakarta: Atma Jay Press

Barth, Prederick, 1982. Ethnic Group and Its Limits. Jakarta UI Press.

BPS. 2017. Indonesia dalam angka. Jakarta: Biro Pusat Statistik

BPS. 2018. Indonesia dalam Angka. Jakarta: Biro Pusat Satatistik

Brink, O. David. 2001. Millian Principles, Freedom of Expression and Hate Speech. In Journal Legal Theory. No. 7. pp.119-157

Bungin, Burhan. 2008. Penelitian Kualitatif. Jakarta: Kencana

Creswell. 2014. Research Design: Pendektana Kualitatif, Kuantitatif dan Mixed. (Diterjemahkan:Ahmad Pawai). Jakarta: Pustaka Pelajar 2015. Penelitian Kualitatif dan Desain Riset, Memilih Diantara Lima Pendekatan.

(Diterjemahkan: Ahmad Lintang). Jakarta: Pustaka Pelajar.

Fichers, Cluade. 1980. Theories of Urbanise. In: George Gmelch \& Walter P. Zenner (ed) Urban Life Reading in Urban Anthropology. New York: St. Marthins.

George, Gemelack, L. Zenner P, Walter. 1980. Urban Life Reading in Urban Anthropology, New York: St. Marthins Press 
Hasbullah, et al (2018). Communication Pattern of Wilayatul Hisbah, Lhokseumawe City in Implementing Amar Makruf Nahi Mungkar. Budapest International Research and Critics Institute-Journal (BIRCI-Journal); 194-205.

Horton. 1991. Sosiologi. Jakarta: Rajawali Press

Khalil, M., et al (2019). Implementation of Marriage in the Period of Armed Conflict in Aceh. Britain International of Humanties and Social Sciences (BIoHS) Journal; 16-25.

Kyulicka, Willy. 2003. Kewarganegaraan Multikultural. Jakarta: Gramedia

Koentjaraningrat. 1977. Metode Penelitian Masyarakat. Jakarta: Gramedia 1990. Manusia dan Kebudayaan. Jakarta: Gramedia

Madjid, Nurcholish (Ed). 2001. Passing Over (Melintas Batasa Agama). Jakarta: Gramedi

Ma'mun. H. 2012. Potret Hubungan Etis dan Agama di Jakarta. Jakarta: Referensi

Massaro, MT. Equality and Freedom of Expression. In Jurnal The Hate Speech Dilemma. Vol. 32. Issue 2. pp.211-265

Napitu, U. (2020). Tural phenomenon of Monument Building in Batak Toba People Life in Pangururan District and Palipi District Samosir. Budapest International Research and Critics Institute-Journal (BIRCI-Journal). P. 1185-1197.

Pamungkas, ASA. 2016. Perspektif Hak Azasi Manusia pada Surat Edaran Kapolri Nomor SE/06/X/2016 dalam penanganan penyebaran ujaran kebencian melalui media sosial. Yogyakarta: Fakultas Hukum Universitas Atmajaya

Purba, N.A.Y., et al. (2019). The Social and Public Health Impacts that Occurred in Rantau Utara Subdistrict after the Publication of the Labuhanbatu District Regulations No.10 of 2011 About the Swallow Bird Tax, Indonesia. Britain International of Humanties and Social Sciences (BIoHS) Journal; 64-73.

Rusdiana, A and Suryana Yaya. 2015. Pendidikan Multikultur. Bandung: Pustaka Setia

Sartono Kartodirdjo. 1993. Integral Nasional: Yogyakarta, UGM

Sitohang, Veryanto, 2011. Lahir untuk Merawat Pluralism. Medan, Hivos

2012. Sumatera Utara Rawan Untuk Kemerdekaan Beragama dan Berkeyakinan Medan: Hivos

Suhadi, Idup \& Sinaga AM. 2006. Wawasan Kebangsaan Dalam Rangka Negara Kesatuan Republik Indonesia. Jakarta: LAN Press

Syahayani, 2015. Hate Speech dalam Ruang Kebebasan Berpendapat. Dalam Jurnal The Indonesia Institute. Vol. IX. No. 12. hal 2-5

Wahab, Jamit A. 2015. Harmoni di Negeri Seribu Agama. Jakarta: PT. Elex Media Komputindo.

Wijaya, Yahya. 2015. Studi Lintas Agama Mendamaikan Teologi dan Studi Agama: Dalam Mengelola Keragaman di Indonesia. Ed. Bernard Adeney Risakota. Yogyakarta: ICRS Mizan

Zed, Mustika. 2008. Metode Penelitian Kepustakaan. Jakarta: Yayasan Obor.

Fatwa Majelis Ulama Indonesia Nomor 24 Tahun 2017. Tentang Hukum dan Pedoman Bermuamalah Media Sosial, 13 Mei 2017. Jakarta.

Surat Edaran Kapolri Nomor SE/06/X/2015 tentang Penanganan Ujaran Kebencian (Hate Speech), butir f dan $\mathrm{g}$.

Undang-undang Republik Indonesia nomor 2 tahun 2002 a). Tentang Kepolisian Negara Republik Indonesia, Jakarta: Sekretariat Negara.

Undang-undang Republik Indonesia nonor 3 tahun 2002 b). Tentang Pertahanan Negara. Jakarta: Sekretariat Negara.

Undang-undang Republik Indonesia nomor 34 tahun 2004 Tentang Tentara Nasional Indonesia, Jakarta: Sekretariat Negara. 